\title{
WETENSKAP EN ETIEK
}

\section{J A HEYNS}

\section{INLEIDEND}

1.1 Vanuit ' $n$ bepaalde opvatting van wetenskap en etiek kan die vraag met reg gevra word of daar enige verband hoegenaamd tussen wetenskap en etiek bestaan. Het ons hier nie met twee eiesoortige geesteshandelinge van die mens te doen waarvan één, nl. die wetenskap, volledig waardevry is, terwyl die ander, nl. die etiek volledig waardebepaald is nie?

1.2 In hierdie kort artikel wil ons die standpunt stel en probeer verdedig dat bogenoemde opvatting prinsipieel onhoudbaar is en dat dit nie alleen lei tot 'n verarming van die wetenskap nie, maar ook die wese van die etiek ernstig aantas. Ten einde dit te kan doen, wil ons eers duidelikheid kry oor die begrippe etiek en wetenskap alvorens ons die saak verder kan beredeneer.

\section{WAT IS ETIEK?}

2.1 Etiek is die wetenskap van die etiese, maar presies wát is die etiese? Die etiese het te doen met die handelinge van die mens - daarby is uiteraard sy gesindhede rondom, sy motiveringe vir en die wyse van die voltrekking van sy handelinge, ingesluit. Dit beteken egter nie dat alle handelinge van die mens, etiese handelinge is nie. Alleen daardie handelinge wat op die persoon van die mens - en dan met name op die persoon van homself en op die persoon van die ander mens - betrekking het, kan as etiese handelinge aangedui word. Etiese handelinge is dus daardie handelinge wat die persoon van die mens, sy status en sy funksie, sy roeping en sy bestemming, sy wese en sy toerusting, raak. Die vraag na goed en kwaad ten opsigte van die persoon van die mens, is die etiese vraag. Nog korter saamgevat: die etiese is persoonsbehandeling.

2.2 In die begrip persoonsbehandeling gaan dit letterlik om die wyse waarop die persoon van die mens behandel word. Maar dit gaan tog ook om meer: in die begrip be-handeling moet hand ook as pars pro toto verstaan word. Die hand is immers net ' $n$ deel van die geheel van die instrumentarium waarmee die persoon van die mens toegerus is: hy het 
ook 'n hart, oog, oor, mond en voet en verrig daarmee dienooreenkomstig aktiwiteite. Die totaliteit van al daardie handelinge word met die begrip persoonsbehandeling uitgedruk. As ons nou die etiese bloot as persoonsbehandeling omskrywe, is dit duidelik dat die behandeling van die persoon na twee kante toe kan uitgaan: dit kan hom bevoordeel en sy welsyn dien, of dit kan hom benadeel en dus skade berokken. Die persoonsbehandeling geskied dus volgens bepaalde norme. Wanneer die behandeling van die persoon van die mens in ooreenstemming met die liefdesgebod geskied, is die handeling eties goed, en het ons met die positiewe waarde van persoonseerbiediging te doen. Maar wanneer dit nie volgens die eise van die liefde geskied nie, dog uit "onliefde" - as samevatting van alle, aan die liefde teenoorgestelde norme - is die handeling eties sleg, en het ons met die negatiewe waarde van persoonsbehandeling te doen.

2.3 Dit is duidelik dat die persoonsbegrip van fundamentele betekenis vir die etiese is. Omdat dit vir ons om teologiese etiek gaan, gaan dit dus om die lig wat die openbaring werp op die persoon van die mens en die wêreld waarin hy leef. Nie alleen is die persoon van die mens deur Gods Woord as sy beeld en gelykenis geskep nie, hy is ook ' $n$ deur die Woord aangespreekte wese en is ook vir sy voortbestaan van Gods Woord onvoorwaardelik afhanklik. Hierdie radikale en totale Woordbepaaldheid van die menslike bestaansituasie én sy leefwêreld, laat die mens ten diepste sien as persoon: as unieke subjek waarin selfs sy liggaam deel van sy subjekwees uitmaak, as aangesproke en daarom ook antwoordende wese, as selfbewuste maar ook as 'n op die werklikheid gerigte wese, as sinontdekkende en as sinrealiserende wese, as draer van verpligtinge en van regte, as gelykwaardig met alle ander mense en tog nie gelyk aan elke ander mens nie. Ons wil met hierdie enkele voorbeelde sê dat die besondere in en aan die mens, d.w.s. die tipies en uniek menslike, in die begrip persoon uitgedruk word. Dit is nie alleen die oord waar die mens tot selfidentifikasie kom met betrekking tot sy eie roeping en taak, sy eie gawes en talente, sy eie wil en begeerte nie, maar ook die oord van waaruit hy homself transendeer en hom in sy fundamentele openheid bekendstel - na God, na sy naaste en na die wêreld. $W(w)$ oordwese is 'n substansiebegrip en ' $n$ relasiebegrip. Die eerste beteken dat hy iemand is met iets - eenmalig, onherhaalbaar, onomruilbaar, die tweede beteken dat wat hy is, hy nie is in die geslotenheid van 'n geisoleerde, selfgenoegsame bestaan nie, maar dat hy die moontlikhede het vir, die behoefte het aan en die vaardighede het tot kommunikasie - en in die proses waarin en die wyse waarop dit alles realiseer word, word ook sy persoonlikheid geopenbaar. Individualiteit 
en sosialiteit is twee legitieme aspekte van die menslike persoonwees sodat die persoon dus nie in één van hierdie aspekte volledig opgaan nie. Hy bly steeds meer. As dinamiese en in vryheid ontwikkelende, ontplooiende en verdiepende grootheid, is die persoon van die mens ook nooit te fikseer in 'n enkele gesindheid, woord of daad nie, en nooit te reduseer tot 'n geobjektiveerde geval, faktor of nommer nie. Waar dit gebeur word die mens in sy menswees gedegradeer, en die persoon van die mens verneder en gekwets.

2.4 In die persoonwees van die mens word die diepste kern van menswees uitgedruk. Daarin word teruggevind nie alleen die tipies universeelmenslike nie, maar ook die tipies individueel-menslike. Nou: waar die mens sy eie persoon só behandel en ook deur ander só behandel word, dat hy sy deur God bepaalde bestemming kan realiseer, daar word die mens eties goed behandel. En omgekeerd: waar die mens, sy eie persoon dus, só behandel word, dat hy aan sy bestemming nie beantwoord nie, daar word die mens eties sleg behandel. Die etiese - só omskrywe - is die studieveld van die etiek. Waar die mens dus ook al betrokke mag wees, dáár handel die mens - ók - eties, en daar is die etiek besig om die etiese op 'n wetenskaplike wyse te bestudeer. Maar nou sal ons dit goed moet verstaan: die etiek dra 'n lewens- en wêreldbeskoulike karakter, dit kan met ander woorde Christelik of nie-Christelik wees, Boeddhisties of Judaïsties, humanisties of kommunisties. Die Christelike etiek sal gevolglik nie ' $n$ blote leer oor die sedelik-handelende mens opstel nie, maar sal vra na Gods openbaring oor die sedelike-handelende mens. Met ander woorde: die Christelike etiek sal normatief én empiries, voorskrywend én beskrywend te werk gaan. 'n Moontlike misverstand moet onmiddellik ondervang word: die Christelike etiek waaroor ons dit hier het, is nie 'n selfstandige wetenskap naas of teenoor die wetenskap van die teologie, die wysbegeerte en die vakwetenskappe nie. In hierdie konteks dui die begrip Christelike etiek daardie wetenskaplike aktiwiteite aan wat die etiese dimensie in al die besondere wetenskappe in die lig van Gods openbaring bestudeer. Daarom moet eintlik gepraat word van 'n Christelik-teologiese etiek, 'n Christelik-wysgerige etiek en 'n Christelik-vakwetenskaplike etiek.

\section{WAT IS WETENSKAP?}

Na hierdie opmerkinge oor etiek let ons vervolgens op die begrip wetenskap, en maak eers enkele algemene aantekeninge daaroor om daarna 'n definisie van wetenskap te probeer saamstel. 
3.1 Teenoor die werklikheid waarin die mens hom bevind, kan hy op verskillende maniere reageer: hy kan dit probeer ontvlug of dit bewonder, en as hy talente het kan hy sy ervaring in verskillende kunsvorme tot uiting bring: in ' $n$ lied kan hy daaroor ween of daaroor jubel, in 'n boek kan hy daaroor skrywe, en op 'n doek kan hy dit visueel verewig. Hy kan die werklikheid ook gebruik en vorm en daarvoor die tegniek inspan. Maar hy kan die werklikheid ook ken en aan sy kennis 'n bepaalde gestalte gee. Met hierdie aftastende soeke na en 'n ernstige poging om 'n greep te kry op die werklikheid - waarvan die mens weet dat dit op hom gerig is en vir hom bedoel is - moet die wetenskap in verband gebring word. Inderdaad is die wetenskap die mens se intellektueelteoretiese én intellektueel-praktiese vat op die werklikheid, sy houvas aan die werklikheid en daarom ook sy beheer oor en stuur van die werklikheid. Één ding moet baie duidelik wees: wetenskap en werklikheid is nie sinonieme begrippe nie. Die verhouding tussen hierdie twee, is te vergelyk met dié tussen 'n kaart en 'n landskap. Die kaart is nie dieselfde as die landskap nie, maar die kaart verteenwoordig, en verwys na die landskap. Terwyl die mens in laasgenoemde en nie in eersgenoemde leef nie, gebruik hy tog die kaart vir sy oriëntering in die landskap. Anders as die landskap is die kaart egter nie 'n gegewene aan die mens nie, maar ' $n$ skepping van die mens - uiteraard in die nouste gebondenheid aan die landskap.

3.2 Met stellige sekerheid kan nou gesê word dat daar weinig aspekte van die landskap is, waarvan daar nog nie kaarte opgestel is nie. Sonder die beeldspraak gesê: daar is weinig sake in die werklikheid wat nog nie voorwerp van wetenskaplike ondersoek is nie. Die wetenskap speel reeds ' $n$ enorme groot rol in die moderne lewe, en gaan ongetwyfeld 'n steeds groter rol speel. Die menslike lewe gaan al meer deur die wetenskap bepaal word, en die enkeling sal hom al minder van die beïnvloeding van die wetenskap kan ontworstel. Geen wonder dat daar al beweer is: "Ons eeu is 'n eeu van die wetenskap".

3.3 Maar nou moet ons onmiddellik vra: indien die fenomenale ontwikkeling en groter wordende invloed van die wetenskap as onomstootlike feit gekonstateer is, is daarmee tegelyk ook gesê dat dit vir ons hier in die teologiese etiek - eweneens noodsaaklik is om daarvan kennis te neem? Inderdaad is die verbinding tussen wetenskap en etiek nie vir almal so vanselfsprekend as wat dit moontlik mag lyk nie. Wetenskap en etiek - so lui die argument - het elkeen só met eie sake te doen dat dit geheel en al buite die terrein en dus buite die belangstelling van die ander een lê. In die etiek gaan dit om waardes en m.n. om die normering 
van die sedewet, terwyl dit in egte wetenskap alleen om feite en nie om waardes - ook nie om etiese waardes - gaan nie.

3.4 Hierdie standpunt kan ons nie onderskryf nie. Ons meen dat die wetenskap - soos trouens ook arbeid en tegniek - tot die kultuurtaak van die mens behoort wat nie sonder norme - en met name ook etiese norme - beoefen kan word nie. Etiek en wetenskap is met mekaar te verbind. Trouens, só intiem is hierdie verhouding, dat ons in die wese van die wetenskap self ' $n$ etiese dimensie sal moet onderskei. En daarom. is ons verplig om ook in die teologiese etiek oor die wetenskap te handel - uiteraard natuurlik net in soverre dit vir ons doel van belang is. Laat ons derhalwe begin met opmerkinge oor die wese van die wetenskap.

3.5 In die woord wetenskap kry ons duidelik die woord wete terug, en wete het met kennis te doen, want iemand wat weet het ook kennis. Goed bekyk,kan ons ten minste drie soorte kennis onderskei: allereers 'n vóór-wetenskaplike kennis. Hierdie kennis wat hoofsaaklik met die dat van dinge te doen het, is 'n praktiese en naïewe kennis, is as sodanig bolangs, oppervlakkig en tot die buitekant van die dinge beperk. Vervolgens kry ons 'n wetenskaplike kennis. Wanneer die kennis van die dat van dinge, ook na die binnekant van die dinge deurdring, om van dááruit die wat, die hoe, die waarom en die waarheen van die dinge agter te kom, gaan die kennis geleidelik oor na wetenskaplike kennis. Wetenskap is dus kennis, maar alle kennis is nie wetenskaplike kennis nie. Met die alledaagse, vóor-wetenskaplike kennis moet nog iets gebeur, alvorens dit as wetenskaplike kennis gekwalifiseer kan word. Uiteraard kan die twee fases nie skerp en helder van mekaar onderskei word nie, maar die een vloei geleidelik in die ander oor.

Beteken dit nou dat alle vóór-wetenskaplike kennis uiteindelik wetenskaplike kennis word? Is daar nie 'n soort kennis wat nooit wetenskaplike kennis kan word nie? Dit skyn my dat hierop positief geantwoord sal moet word. Ons sal inderdaad moet praat ook van buitewetenskaplike kennis. Dit is 'n tipe kennis - bepaal deur die voorwerp van kennis - wat nie uitloop op of uitmond in wetenskaplike kennis nie, omdat die prosesse wat vóór-wetenskaplike kennis in wetenskaplike kennis omskep, nie op daardie tipe kennis toegepas kan word nie. Voorbeelde van hierdie soort kennis is o.a. kennis van kuns en van tegniek.

3.6 Ons sou wetenskap dus soos volg kan definieer: dit is gesistematiseerde en geverifieerde, abstraherende kennis van die werklikheid. Uit hierdie kort omskrywing is veral twee sake vir ons van belang: ten eerste, wetenskap is ' $n$ uiters belangrike deel van die menslike 
kultuurontsluiting en het as sodanig as primêre doel die ver-Heer-liking, d.w.s. die Heer-erkenning van God, en as sekondêre doel die bewoonbaarmaking van die aarde (vgl. Jes. 45:18). Ten tweede, wetenskap is eweneens ' $n$ uiters belangrike deel van menswees, en met name van daardie bepaalde manier van menswees wat op 'n kennisverowerende, metodies-antwoordende, krities-afwegende wyse voltrek word. Wetenskap en mens kan dus nie van mekaar geskei word nie, en daarom ook nie wetenskap en die etiese nie. Maar presies waarin is nou die etiese in die wetenskap aan te wys?

\section{DIE ETIESE DIMENSIE VAN DIE WETENSKAP}

4.1 Allerlei onderskeidinge en indelinge in die wetenskap soos o.a. dié in geesteswetenskappe en natuurwetenskappe, of dié in teologie, wysbegeerte en vakwetenskappe, is vir ons hier nie ter sake nie. Dat die etiese in elkeen van die wetenskappe aanwesig is en elke wetenskap dus fundamenteel bepaal, trouens, selfs as die integrerende faktor in elke besondere wetenskap funksioneer, is vir ons veel belangriker as die feit dat die etiese nie in elke wetenskap of in elke groep wetenskappe presies op dieselfde evidente manier aanwesig is, presies dieselfde appél of presies dieselfde reikwydte het nie. Dit gaan vir ons nie om die fynere nuanseringe nie, maar om die groot waarheid, nl. dat die etiese wesenlik deel van die wetenskap is - ongeag die soort of tipe van wetenskap. Eie aan die wetenskap is nie net die rasionele, metodiese, logiese of kenteoretiese aspekte nie, maar ook die etiese. Want intiem gemoeid met die wetenskaplike aktiwiteite is ook die kwaliteit van handelinge wat die persoon van die mens fundamenteel raak. Juis die aanwesigheid van verskillende aspekte in die wetenskap en die ernstig neem van die aktualisering van die etiese kan 'n konflik teweegbring of openbaar tussen die etiese en die ander aspekte. So kan dit gebeur dat daar terwille van kennisvermeerdering eksperimente uitgevoer behoort te word wat eties nie toelaatbaar is nie. Maar kennisvermeerdering kan ook weer nuwe dimensies in die etiese self openbaar. Want nuwe kennis skep nuwe moontlikhede van beskouinge en handelinge. Daarmee is ook gesê dat daar nie noodwendig ' $n$ kontinuïteit van gestalte bestaan waarin die etiese voortdurend gegiet word nie. Inteendeel. 'n Pluriformiteit van gestaltes het ontstaan en is nog steeds besig om te vermeerder wat saamhang met die kennisontwikkeling, met nuwere insigte en met die eksperimentele karakter van die menslike bestaan. Tog word alle gestalteverandering genormeer deur die universele etiese norme wat uitdrukking gee aan wat die mens na sy diepste wese behoort te wees. Ten 
spyte egter van sy sporadiese konflikskeppende werking en sy pluriforme gestaltes van konkretisering, funksioneer die etiese dimensie integrerend én normerend ten opsigte van al die verskillende aspekte van 'n bepaalde wetenskap. En die navorser wat nie geïntegreerd t.o.v. die verskillende aspekte in die wetenskap lewe nie, lewe skisofrenies.

4.2 Wie aanleg vir wetenskapsbeoefening het, en 'n roeping daarvoor ontvang het, en dit in gehoorsaamheid opvolg, vind in die wetenskap 'n belangrike aspek van sy menslike selfverwerkliking en bestemmingsrealisering. Self toegerus met die etiese ontdek die mens dat die wetenskap nie net aan norme in die algemeen nie, maar in besonder ook aan etiese norme onderworpe is. En hierdie normering is legitiem aangesien die wetenskap self, inherent aan sy struktuur as wetenskap, deel het aan die beginsel van die etiese. Wél het elke wetenskap sy eie veld van ondersoek en eie metode waarvolgens die ondersoek gedoen word, en tog is die vraag: hoe word die persoon van die mens daardeur geraak, m.a.w. wat is goed en wat is sleg vir die persoon van die mens, ' $n$ gemeenskaplike vraag aan en probleemstelling vir alle wetenskappe. Met reg kan dus beweer word dat die beoefening van wetenskap as sodanig óók ' $n$ etiese aangeleentheid is. Die wetenskap wat sy naam werd is, sal nie net bewus wees van nie, maar ook sensitief wees vir die waarde van die menslike persoon. Daarbenewens sal nooit vergeet mag word nie dat die wetenskapsbeoefening ' $n$ lang geskiedenis het van menslike samesyn, van menslike beplanning, inspanning en uitvoering. Dit is voorwaar geen oordrewe of ongegronde stelling om te beweer: in die wetenskaplike gaan die mens dood as hy nie ook etikus is nie. Maar juis as gevolg van die aanwesigheid van die etiese dimensie in die wetenskap as sodanig, sal elke navorser genoodsaak wees om op 'n eie manier getrou aan die eise van sy wetenskap - met die etiese besig te wees.

4.3 Die kort omskrywing van wetenskap wat ons vroeër gegee het kan maklik die indruk wek dat die begrip wetenskap alleen die aktuele proses van wetenskapsbeoefening insluit. In 'n engere sin is dit inderdaad ook korrek. Maar dan is daar ook aspekte soos die vóóronderstellinge waarin die wetenskap ingebed is en van waaruit hy in ' $n$ bepaalde rigting gestuur word, en aspekte soos die toepassing van die wetenskaplike resultate waarby die wetenskap ten nouste betrokke is. In 'n ruimere sin word ook hierdie aspekte tot die begrip wetenskap gereken.

4.4 Dit is gevolglik ons oortuiging dat die etiese in die volgende drie aspekte van die wetenskap aanwesig is: in die vóóronderstelling van die wetenskap, in die proses van wetenskapsbeoefening en in die toepassing 
van die wetenskaplike resultate. Aan elkeen hiervan gee ons nou aandag.

\subsection{In die vóóronderstelling van die wetenskap}

4.5.1 Ons sê die etiese is alreeds in die vóoronderstellinge van die wetenskap geleë. Maar nog fundamenteler as hierdie stelling is natuurlik die beantwoording van die vraag of die wetenskap wél vóóronderstellinge het? Daar is 'n standpunt wat hierop ontkennend antwoord aangesien die wetenskap neutraal of waardevry sou wees, want die wetenskap, so word gesê, gaan nie êrens van uit nie, maar gaan net êrens heen, en ten einde dit te bereik moet alle waarde-oordele aangaande teoretiese veronderstellinge met betrekking tot die subjek van die wetenskap, naamlik die mens, of die objek, van die wetenskap naamlik die voorwerp van ondersoek, of die wetenskap self, opgeskort word. Die ondersoeker moet volledig onbevange en onbevooroordeeld die veld van sy navorsing betree, ten einde die spraak van die fenomene wat hy wil ondersoek in sy gees te registreer en verstaanbaar te verbaliseer. Ons gaan hierdie siening nie verder toelig nie. Die beskouing van 'n neutrale wetenskap waarvolgens vooronderstellinge geen invloed op die wetenskapsbeoefening het nie, en ook nie mag hê nie, is na ons mening nie van Calvinistiese oorsprong nie, maar hoort eerder in 'n Lutherse tradisie tuis. Ons volstaan dus met die stelling dat die etiese alreeds in die vóóronderstellinge van die wetenskap aanwesig is, en dat daar dus eties normerende basisveronderstellinge bestaan, wat vir wetenskapsbeoefening van grondliggende betekenis is. Dié stelling wil ons nou nader toelig.

4.5.2 Waarskynlik kan die onderskeiding in twee tipes vooronderstellinge vir ons doel goeie diens doen: allereers dié wat vir die interne proses van wetenskapsbeoefening noodsaaklik is, en vervolgens - wyer en breër dié wat van 'n algemene lewens- en wêreldbeskoulike aard is.

4.5.3 Ons opmerkinge oor die eerste tipe vooronderstellinge wil ons begin deur die aandag te vestig op die mens se betrokkenheid by en sy verantwoordelikheid ten opsigte van wetenskapsbeoefening. Die mens wat geroep is om hom met wetenskapsbeoefening besig te hou, is as hele mens daarby betrokke: sy rede, wil en gevoel is daarin werksaam. Maar dan sal ons dit goed moet begryp: wél is ál die funksies van die mens by sy kennende omgang met die werklikheid betrokke, maar dit is tog nie die funksies in hulle totaliteit nie. Wie immers met sy hele hart, en sy hele siel en sy hele verstand die wetenskap liefhet en dit so ook beoefen, maak van die wetenskap 'n afgod, want só mag 'n mens God 
alleen liefhê (Mat. 22:37). Tussen hele mens en totale mens sal ons dus moet onderskei. Dit is derhalwe eties verantwoord - vir die geroepene - om as hele mens by die wetenskap betrokke te wees, maar nie as totale mens nie: van 'n totalitêre betrokkenheid mag alleen tussen God en mens sprake wees. Dit geld natuurlik nie net die individuele mens nie, maar ook ' $n$ groep mense, en met name instansies wat met wetenskapsbeoefening besig is.

4.5.4 Betrokkenheid by wetenskapsbeoefening impliseer vanself ook verantwoordelikheid ten opsigte daarvan. Van buitengewone groot belang in hierdie verband is die feit dat die mens se verantwoordelikheid enorm toegeneem het. Die aanvanklike beskouing dat die orde van die natuur 'n vasstaande gegewene is met betrekking waartoe die mens sy weg slegs waarnemend, beskrywend en kennend kan gaan, het sy verantwoordelikheid uiteraard drasties ingeperk. Daarom het die etiek aanvanklik dan ook op die mikrovlak van die individuele etiek bly steek. Geleidelik is egter ingesien dat die orde van die natuur self in ' $n$ wordingsproses begrepe is, en as ' $n$ bewerkbare grootheid tot die mens se beskikking staan. Die mens wat hom met wetenskapsbeoefening besig hou, bevind hom onontwykbaar geplaas voor die vraag: in hoeverre word die menslikheid van die mens gedien deur die wetenskaplik ontwerpte leefwêreld? Met hierdie oorgang na die makrovlak van struktuuretiek het die mens se verantwoordelikheid kwantitatief en kwalitatief op 'n byna onberekenbare skaal toegeneem.

4.5.5 Nie net die lewe in die algemeen nie, maar die wetenskapsbeoefening in die besonder, is ' $n$ proses van antwoorde - voortdurend opnuut moet antwoorde op voortdurend opnuut gestelde vrae en uitdaginge gegee word. En ten opsigte van hierdie verpligting-tot-antwoord-gee kán en mág geen mens homself buite spel plaas nie. Wie dit sou probeer, ontduik daarmee sy verantwoordelikheid en tas sy menssyn in sy diepste wese aan. Elke beoefenaar van die wetenskap moet gevolglik ' $n$ helder visie hê van wat sy amp aan etiese verantwoordelikheid inhou, en voortdurend sy ampsetos, d.w.s. sy eie konkretisering van die etiese, aan die daarvoor geldende norme toets. Hier kom ter sprake o.a. die volgende: sy verantwoordelikheid teenoor homself. Gemotiveer deur sy roeping en gedryf deur die tipies menslike eienskappe van nuuskierigheid en weetgierigheid, sal 'n eerlike soeke na die waarheid sy hele wetenskaplike bedrywigheid kenmerk. Eersug en ydelheid, onwaaragtigheid en hoogmoed mag nie by hom aangetref word nie. Verantwoordelikheid teenoor sy medewerkers. Die beoefenaar van die wetenskap sal steeds gewillig moet wees om met ' $n$ openheid van gees van elke ander weten- 
skaplike, of dit sy mindere en of dit sy meerdere, sv aeesaenoot of 'n andersdenkende is, te leer. Hulle sal mekaar aanmoedig en stimuleer en mekaar vrymoedig korrigeer want die gemeenskaplike ideaal van vryheid in en deur die waarheid, verhef hulle bo die kleinlikheid van naywer en afguns en stel hulle in staat om tot mekaar se ontplooiing en groei by te dra. Verantwoordelikheid teenoor die mensheid. 'n Blote teoretiese en/of eksperimentele aangeleentheid los van sy gerigtheid op die welsyn van die ganse mensheid, is wetenskapsbeoefening nie - of, miskien moet gesê word, nie meer nie. Die wetenskap staan ook in diens van die gemeenskap en word geroep om mede die vooruitgang van samelewingspatrone te stimuleer en te lei.

4.5.6 Die vooronderstellinge wat met die interne proses van wetenskapsbeoefening saamhang - waaraan ons so pas aandag gegee het - hang egter saam met, wys heen na en word ook fundamenteel bepaal deur vooronderstellinge wat ' $n$ algemene lewens- en wêreldbeskoulike karakter vertoon. Hieraan wil ons nou aandag skenk.

4.5.7 Die aktualisering van die etiese in die wetenskap word medebepaal deur die algemene lewens- en wêreldbeskoulike vooronderstellinge waardeur die wetenskap self gedra, gerig en gelei word, waaraan die wetenskap selfs sy ontstaan te danke het, en dus sy sin, doel en taak ontleen. Die fundamentele sekerheid en vastheid waarna die wetenskap t.o.v. kennis streef, kan die wetenskap slegs verkry van 'n geloof aan dieper, wetenskaplik onbewysbare, gronde - wat uiteindelik net deur die lewens- en wêreldbeskouing voorsien kan word. Hierdie fundamentele aard van sekere en vaste kennis hang saam met en vloei voort uit die religieus-etiese aard of grondmotief van die lewens- en wêreldbeskouing self. Laasgenoemde ken immers as wesenlike bestanddeel, ' $n$ gerigtheid op God of, afvallig, op iets wat in die plek van God gestel word. Dit ken ' $n$ geloof aan die lewende God of aan die verabsoluteerde rede van die mens, of aan verabsoluteerde feite, of aan die verabsoluteerde wet, of aan die verabsoluteerde voorspoed of verabsoluteerde meerderwaardigheid van die enkeling, groep of eie volk. So het die Christelike, humanistiese, pragmatistiese, hedonistiese, eudaimonistiese, eksistensialistiese en ander lewens- en wêreldbeskouinge fundamentele invloed op die wetenskap. Dit funksioneer as 'n perspektief en 'n konteks vir die menslike blik en toon iets van die dinamiek en motivering van menslike beslissing. Ons kan ook sê dit vervul die funksie van 'n horison wat ' $n$ aanduiding is van waarheen die mens met-die-deur-diewetenskap-"gevatte"-werklikheid op weg is. Veronderstellinge van hierdie aard - waarin opvattinge oor en bepaalde konsekwensies vir die per- 
soon van die mens en die mensheid as geheel aanwesig is - speel eksplisiet en implisiet hul onvermydelike rol in wetenskapsbeoefening. 'n Kritiese ondersoek na en 'n eerlike evaluering van die diepste lewens- en wêreldbeskoulike vooronderstellinge waarmee hy werk, is derhalwe 'n plig en 'n gewetensaak vir elke wetenskaplike. Wie dit nie doen nie, of selfs ontken dat dergelike vooronderstellinge ' $n$ invloed op hom het, handel eties afkeurenswaardig.

4.5.8 Waar 'n konsekwent Christelike lewens- en wêreldbeskoulike vooronderstelling die grondslag van wetenskapsbeoefening gemaak word, word nie net ander duidelike geformuleerde lewens- en wêreldbeskouinge afgewys nie, maar word ook 'n prinsipiële verset geloods teen die moderne gesekulariseerde of geprofaniseerde lewens- en wêreldbeskoulike oortuiging. In die voortgaande proses van profanisering waarin elke herinnering aan Christelike beginsels, norme en waardes al hoe meer wegval, en die selfgenoegsame mens sonder enige bewuste nie-aardse verbindinge, as outonome singewende subjek optree, is die moderne laboratoria al die tempels van die profane godsdiens genoem. En kan die wetenskap met sy maggewende kennis en die tegniek met sy maguitoefende gereedskap met reg die religieuse simbole van die profane lewe genoem word.

4.5.9 As die Christelike lewens- en wêreldbeskoulike vooronderstellinge in die één enkele omvattende begrip t.w. die koninkryk van God uitgedruk word, en ons dit in sy grondbestanddele - wat vir wetenskapsbeoefening van belang is - gaan opbreek, lyk dit soos volg:

(a) God bestaan en het Hom aan die mens geopenbaar. Geloof in 'n persoonlike God wat Hom aan die mens geopenbaar het, druk 'n duidelike stempel op die wetenskap af. Natuurlik is 'n geloofsoortuiging ' $n$ hoogs persoonlike aangeleentheid en bly die geloofsakte 'n subjektiewe handeling, maar die geloofsinhoud is objektiveerbaar, d.w.s. kan in sisteme en stelsels, strukture en institute ingebou word. En in die sin kan ons sê, bly die geloof nie verborge nie, maar word in konkrete gestaltes tot uitdrukking gebring. Geloof in God maak die mens nie blind vir die kennis waarna die wetenskap soek nie. Inteendeel. Die geloof maak die mens vry en bind hom aan die waarheid. ' $n$ Streng skeiding tussen geloof en wetenskap is op prinsipiële grond nie te verdedig nie, en prakties nie te hanteer nie. Wie in die geloof met God saamlewe, kan ook met die kenbare wêreld saamlewe en tot kennis kom. Die God wat in die geloof geken word, is immers ook die Skepper van die wêreld wat in die 
wetenskap bestudeer word. En $\mathrm{Hy}$ is dit wat die werke van sy hande aan die in Hom gelowige mens openbaar. Geloof en wete vorm geen dualisme nie. Geloofskennis en wetenskaplike kennis $k a n$ in één mens saamkom, sonder enige verdeling tussen hart en verstand. Die etiese aspek lê in die integrasieopdrag: dat één mens, 'n onbevange en krities-denkende ondersoeker, tegelyk volledig erns met sy geloof kan maak en in albei eerlik en toegewyd kan wees. En wie volledig erns maak met sy geloof in God, kan die wetenskap nie verabsoluteer nie. Hierdie lewenshouding wat ons sou kon noem scientokrasie, bekyk alles met die bril van die wetenskap, verwag alles van die wetenskap, beoordeel alles in die lig van die wetenskap, laat die wetenskap oor alles die laaste woord spreek en verwerp alles of ontken die waarde van alles wat nie meetbaar en berekenbaar is nie. Dit is teologies-eties gesien nie in orde om die bestaan van God as Skepper van alles en Heer oor alles te bely en dan te maak asof dit geen betekenis het vir die beskouing van die wese en funksie van die wetenskap en geen invloed het op die beoefening van die wetenskap nie.

(b) God het die aardse werklikheid en die mens na sy beeld geskep. Die skepping is deur die Skepper vir die skepsel bedoel, en Hy rig die skepping as vraag, beter, as vraende werklikheid, aan die mens. Daarom is die skepping ' $n$ teoreties bedenkbare, begripsmatig kenbare en 'n prakties bewerkbare werklikheid, terwyl die mens op ' $n$ besondere wyse as mede-arbeider deur God, vir die verwerkliking van sy doel met die skepping, gebruik word. Met die oog op die bewerking van die aardse werklikheid neem God die mens in sy hand en plaas in die hand van die mens o.a. die wetenskap. En só alleen: as hand in die hand van die mens geplaas in die hand van God, mag die wetenskap gebruik word. Die mens wat só nie wil leef nie, en die wetenskap só nie wil gebruik nie, is nie net ongehoorsaam aan God nie, maar ook oneerlik teenoor homself en teenoor alle ander mense wat deur sy wetenskapsbeoefening geraak word.

(c) Die mens het hom in sonde teen God verset en doen dit nog steeds. In feite was die historiese sondeval nie ' $n$ val na onder nie, maar 'n sprong boontoe - 'n greep na God en ' $n$ wil-wees-soosGod. Daardeur het die mens uit God se bedoeling met sy lewe uitgeval, en is alles wat die mens doen met sonde besmet - ook die wetenskap. Daarom gebruik die mens ook die wetenskap teen God en Sy werke, teen die mens en sy welsyn, en wel in belang van 
homself. Wie hierdie toedrag van sake nie erken en daarmee nie rekening hou nie, sal die demoniese ontaarding van die wetenskap en die bedreiging wat dit vir die mens en sy bestaan op aarde inhou, nie kan beveg en teengaan nie.

(d) God het die sondaar nie verwerp nie, maar aan hom in Jesus Christus genade bewys. Die sonde, en daarom ook die ontaarding van die wetenskap kan egter nie deur die mens self nie, maar deur Jesus Christus alleen oorwin word. Daarom maak $\mathrm{Hy}$ en $\mathrm{Hy}$ alleen, die mens weer mens, en die wetenskap weer wetenskap volgens God se bedoeling. En die mens wat in Christus glo, gaan ook uit die genade van Christus lewe. So word hy dan die kanaal en die instrument waardeur die genade helend die sondige wêreld binnedring, en ontdek hy nie net God as God nie, maar ook homself as mens, die wêreld as wêreld, en die wetenskap as wetenskap. Die genade beteken immers vryheid tot identiteit. Ons sou dus kon sê: om ook in die wetenskapsbeoefening bewustelik uit die genade van Christus te lewe, is om die wetenskaplikheid van die wetenskap, en die menslikheid van die mens te waarborg. Wie dit nie doen nie, weier om aan die eis van identiteit te voldoen en handel eties afkeurenswaardig.

4.5.10 Die lewens- en wêreldbeskoulike vooronderstellinge is nie sonder etiese elemente nie. Ons het dit kortliks aan die hand van die Christelike lewens- en wêreldbeskouing probeer aantoon. Dit is ons eerste poging om die etiese dimensie van die wetenskap te illustreer. Nou volg die tweede.

\subsection{In die proses van wetenskapsbeoefening}

4.6.1 Die verantwoordelikheid van die beoefenaar van die wetenskap begin konkreet reeds by die bepaling van die prioriteite van sy navorsingsprogramme. Nie alles wat gedoen behoort te word, kan gedoen word nie. Baie faktore, o.a. finansiële oorweginge, noodsaak 'n keuse. Die motiewe wat in die opstel van 'n rangorde van temas 'n rol speel, sal nugter oorweeg moet word en eties aanvaarbaar moet wees. Ewe belangrik is dat nie alles wat wél gedoen word, teen enige pryse gedoen mag word nie. Die koste o.a. sal deeglik bereken moet word. En in geen geval mag die mens aan die wetenskap opgeoffer word nie. Die etiese norm bly steeds dat die wetenskap die mens dien, en nie omgekeerd nie.

4.6.2 Die proses van wetenskapsbeoefening deurloop 'n aantal fases. 
Om die etiese dimensie daarvan aan te toon, hoef ons nie al die fases logies op die spoor te volg nie. Ons gaan slegs by enkeles daarvan stilstaan en dit bloot met trefwoorde aandui.

4.6.3 Kennis. Die doel van die wetenskaplike is om van sy veld van ondersoek kennis te verwerf. Dit impliseer dat die mens ' $n$ wese is wat die aanleg het om te kan ken en dat die kosmos wat bestudeer word, kenbaar is. Die mens se kenaanleg behels onder andere waarneming en denke. Op grond van waarneming deur middel van sintuie, weerstandservaring, waardekeuring, intuïsie ens., word die mens van die kenbare bewus. En met behulp van die denke word begrippe, oordele, gevolgtrekkings, modelle, teorieë en sisteme gevorm. Dat hierdie unieke proses van kennisverwerwing die grootste verantwoordelikheid, delikate onderskeidinge en fyn sensitiwiteit van die wetenskaplike vereis, spreek van self. Sy waarneming en denke moet van alle elemente daarvan gebruik maak - en wel in die juiste verhouding - wil hy tot betroubare en ware kennis kom. Sekere elemente daarvan mag nie verwaarloos of selfs volledig geëlimineer word ten einde ' $n$ bepaalde vooropgesette eindresultaat te verkry nie. Waar sy waarneming en denke op die mens - individueel of kollektief - gerig is, sal dit steeds die waardigheid en die uniekheid van die menslike persoon moet eerbiedig.

4.6.4 Waarheid. Die wetenskaplike wil met sy kennis die werklikheid begryp, en dit beteken konkreet dat hy met sy teoretiese begrippe die werklikheid vasgryp. Met hierdie vasgegrypte werklikheid kan hy o.a. twee dinge doen: hy kan dit aan ander deurgee en dan kan hulle of hy self in die teoreties vasgegrypte werklikheid ook prakties ingryp. Kennis wat die mens hiertoe in staat stel, is ware kennis. Inderdaad gee ware kennis (iets van) ' $n$ greep op die werklikheid, en voorsien daarom vastigheid en koers, rustigheid en geluk. Nie in die intellektuele aktiwiteite as sodanig is geluk dus geleë nie - soos die eudaemonistiese etiek van Aristoteles dit voorstel nie - maar in die waarheid van die kennis. Daarom mag kennis die waarheid en die waarheid alleen dien en geen ander doel nie. Die waarheid bied genesing vir die onrustige gees van die mens; die waarheid gee aan die kennis die grond vir sy mag; die waarheid stel die mens in staat om met sy kennis op ' $n$ menslike wyse te stry vir 'n menslike bestaan. Waar kennisverwerwing gerig is op die waarheid, daar sal gevolglik nie net toewyding aan die taak nie, maar ook respek vir die gegewens, 'n objektiewe instelling en 'n vermyding van 'n subjektivistiese benadering, aangetref word. Waar liefde vir die waarheid die dominerende motief is, is daar nie plek vir naywer of wetenskaplike oneerlikheid uit bymotiewe nie. Ons het gesê: ware kennis het te doen 
met 'n greep op die werklikheid, en laasgenoemde weer het te doen met die ont-dekking van die werklikheid. Maar dit sal dan goed begryp moet word. Die werklikheid is 'n deur die sonde gebroke werklikheid. Daarom is waarheid nie die blote ont-dekking van die werklikheid in die mens se proses van kennisverwerwing nie. 'n Teoreties-geverbaliseerde replika van die werklikheid, is nog nie waarheid nie. Dit is bloot faktisiteit. Faktisiteit het met die hoe-heid van die werklikheid te doen. Dit beteken dat betroubare kennis ook die leuen en die bose in die werklikheid sal moet ont-dek, d.w.s. die leuen en die bose sal as sodanig ontmasker en kenbaar gemaak moet word. Betroubare kennis is kennis wat ' $n$ insig bied ook in die onbetroubare. Soos daar ' $n$ leuen is oor die waarheid, is daar ook ' $n$ waarheid oor die leuen. En eers waar waarheid heers - ook waarheid oor die leuen - kan egte kommunikasie plaasvind. Die beoefenaar van die wetenskap sal gevoiglik nie net uiters sensitief wees vir die onderskeid tussen waarheid en valsheid in sy kennis van die werklikheid nie, maar sal daardie aspek van die werklikheid wat hy wil ken, ook nie in sy eie perspektivistiese visie inwring nie. Wie nie aan grenslose hoogmoed en verwaandheid lei nie - en so sy eie persoon eties afkeurenswaardig beskou en behandel - sal weet dat die waarheid veel groter is as die grense van sy eie kennis, en dat dit tot die sin van die waarheid en die betekenis van die werklikheid behoort om deur 'n verskeidenheid van menslike kenprosesse gerealiseer te word. En watter mens is hiertoe in staat? Niemand nie. Die mens moet vir die waarheid bevry word, en dit kan alleen deur die geloof in Jesus Christus plaasvind. ' $n$ Bestaan-in-die-waarheid, en 'n liefde-vir-die-waarheid, is ' $n$ gawe van God, wat dan ook deur Hom steeds waar gemaak moet word. Wie die Waarheid ken en deur Hom vir die waarheid bevry is, kan nie en mag nie oor Hom ook in die proses van kennisverowering stil bly nie. En wie nie oor Hom kan stilbly nie, handel eties goed.

4.6.5 Verifikasie. Dit gaan in wetenskapsbeoefening nie net om kennisinsameling nie, maar ook om toetsing van die versamelde stof. In hierdie proses van verifikasie gaan dit om vas-stelling, om seker-stelling van die resultate en met name om die versekering dat dit aan die kenbare sal beantwoord en dat die verworwe kennis ook ware kennis sal wees. Vir hierdie verifikasie is die navorser allereers self verantwoordelik. Dit is trouens één van die tipiese kenmerke, en moet as 'n etiese deug beskou word, dat die navorser krities m.b.t. homself en die werk wat hy doen, ingestel is. Kritiek kom van die Griekse krinein wat letterlik skei of sif beteken. In die feitelike gegewene word skeiding aangebring tussen sin en sinloosheid, tussen aanvaarbaar en nie-aanvaarbaar, tussen waardevol en niewaardevol. Keurend en siftend gaan die kritikus met sy eie werk om, en 
dit in die veronderstelde wete dat die feitelike van die behoorlike afwyk. Daarom moet die kritiek ook aantoon: antinomieë (innerlike teensprake), inkonsekwensies, sirkelredeneringe, meersinnige woord- en begrippegebruik, ongeldige afleiding, ens. Selfkritiek behoort tot die toerusting van 'n mens wat op die hoogste peil van geestelike volwassenheid beweeg. Maar juis daarom sal die navorser ook gewillig moet wees om sy werk deur ander te laat toets. Ook selfkritiek is immers geen waarborg vir ware kennis nie. Daarom is ook selfkritiek aan kritiek - van buite onderwerp, en behoort ook kritiek van buite tot die navorser se volwasse apparatuur. Meer nog: die toetsing deur ander navorsers gee ook die juiste perspektief op die kollektiewe aard van die wetenskapsbeoefening. Laasgenoemde is nie ' $n$ eenmensonderneming - selfs nie ' $n$ onderneming wat deur één geslag geloods en voltooi kan word nie. Die sekerheid van die wetenskaplike kennis gaan uit bó die individuele en subjektiewe insigte en kennis en bó die getoetsde arbeid van die enkele navorser. Daarom sal ons ook vanuit dié gesigspunt kan praat van die sosiaaletiese aspek van die wetenskapsbeoefening.

4.6.6 Metode. As die veld van ondersoek die beginpunt uitmaak, en kennis daarvan die eindpunt, dan lê tussen die twee die metode wat as handeling voltrek word om van die een na die ander te beweeg. 'n Metode, as ' $n$ bepaalde wyse van handeling, is dus nie ' $n$ doel op homself nie, maar ' $n$ middel en wel ' $n$ middel wat in diens van kennis staan. Uiteraard is daar ' $n$ verskeidenheid van metodes wat gebruik kán en móét word. Eerlikheid sal die navorser verplig om alle beskikbare metodes wat by sy veld van ondersoek pas, te gebruik. Nie alle metodes kan vir alle wetenskappe gebruik word nie. Wat bv. in die teologie gebruik word, kan nie in die wiskunde of in die fisika gebruik word nie. Die keuse en gebruik van metodes word dus deur die veld van ondersoek en natuurlik deur die doel, nl. wetenskapsvorming, bepaal. Wie dié weg nie volg nie, kan nie ware kennis verkry nie. Eweneens sal die navorser die metode steeds as metode moet gebruik. Wanneer die metode egter self as bron van kennis hanteer word, en dus meer van die metode verwag word as wat die metode kragtens sy wese en aard kan bied, word die metode volledig oorspan, en kan ons van wetenskaplike metodisme of van metodistiese afgodediens praat.

4.6.7 Teorievorming. Wanneer al die moontlik bekombare gegewens versamel is, moet daaraan ' $n$ innerlike samehang gegee word - beter gestel: moet die aanwesige samehang sistematies weergegee word. Hierdie proses van teorievorming wat as werkhipotese gebruik word, stel besonder hoë eise aan die deeglikheid en die oorspronklikheid van die 
navorser. Hier veral blyk sy respek nie alleen teenoor die veld van sy ondersoek nie, maar ook vir die innerlike waarde van kennis, en sy sorgsaamheid in die sistematisering daarvan. Steeds sal hy van die voorlopigheid en die onafheid van sy denksisteem bewus wees, want sy basiese openheid van gees sal hom sensitief maak en sensitief hou vir nuwe feite en nuwe interpretasiemoontlikhede van bekende feite. In die fase van teorievorming kan maklik 'n vervalsing van gegewens en 'n doelbewuste ignorering van gegewens plaasvind. Geen wetenskaplike metode of rasionele kennis sal die navorser van dergelike vergrype weerhou of vrywaar nie, daartoe is alleen sy eie integriteit as mens in staat.

4.6.8 In die voorafgaande opmerkinge het ons probeer aantoon dat ' $n$ positivistiese omgaan met en interpretasie van die gegewens wat in die proses van wetenskapsbeoefening versamel word, prinsipieel onhoudbaar is. Onlosmaaklik vervleg met en fundamenteel bepalend vir die verloop van die proses van kennisversameling is die etiese, en wie daarmee nie rekening hou nie en hom nie daarvan rekenskap gee nie, handel onverantwoordelik.

4.6.9 Ten slotte wil ons die aanwesigheid van die etiese dimensie in die wetenskap ook illustreer in die toepassing van die wetenskaplike resultate.

\subsection{In die toepassing van die wetenskaplike resultate}

4.7.1 Die wetenskap is, volgens die moderne opvatting daarvan, nie meer nét ' $n$ teoretiese aangeleentheid, wat agterna ook nog toegepas kan of moet word nie. Dit is selfs nie meer voldoende om te beweer dat die wetenskap bloot net in diens staan van die samelewing nie. Die band tussen wetenskap en samelewing en die beïnvloeding van veral eersgenoemde op laasgenoemde is van 'n veel intiemer aard. Die wetenskap vloei, kragtens sy intrinsieke aard en metodiese opset, oor in die samelewing, sodat die praksis ' $n$ onlosmaaklike deel van die hedendaagse wetenskap geword het. Gevolg hiervan is dat die navorser hom nie kan onttrek aan sy medeverantwoordelikheid t.o.v. die gevolge van sy wetenskaplike ondersoek vir die samelewing nie. Juis hierdie betrokkenheid behoort by die navorser 'n dusdanige etiese verantwoordelikheidsbewussyn te skep en wakker te hou, dat ' $n$ houding van vryblywendheid volledig onmoontlik sal wees. Die wetenskaplike is dus onontwykbaar voor 'n duidelike etiese stellingname t.o.v. die resultate van die wetenskap en die sosiaal-maatskaplike toepassing daarvan geplaas. 
4.7.2 Die wetenskap deel, saam met kultuur in die algemeen, die omvattende doelstelling, nl. die bewoonbaarmaking van die aarde (Jes. 45:18) - wat uiteraard ook die instandhouding van die eenmaal verworwe lewensruimte insluit. Die prinsipieel-etiese vraag wat die toepassing van wetenskaplike resultate blywend normatief moet begelei, is derhalwe die vraag of dit die bou en die bewaring van 'n lewensruimte dien. Waar dit wél die geval is, word eties goed gehandel, maar waar dit nie gebeur nie, word eties afkeurenswaardig gehandel. Juis die geweldige vooruitgang wat die wetenskap t.o.v. kennisvermeerdering en gevolglik ook t.o.v. magsuitbreiding beleef het, het die betekenis van die wetenskap na sy etiese relevansie en geladenheid enorm laat groei. Tans kan die mens, met behulp van die wetenskap, veel meer doen vir die welsyn van die mens as vroeër - of hy dit ook besef, en of hy dit ook wil doen, vloei nie noodwendig daaruit voort nie. Trouens, dit is juis die nood rondom die moderne wetenskap: 'n toenemende kennis, mag en etiese relevansie, maar 'n skreiende gebrek aan insig in die verantwoordelik akademiese gebruik daarvan.

En tog is dit so dat in ons huidige kultuurontwikkeling daar prakties geen ernstige maatskaplike, politieke, ekonomiese en kerklike probleemstelling is, wat sonder wetenskaplike hulp aangepak word nie.

4.7.3 Wanneer kernenergie deur wetenskaplikes geskep word en dit word ook gebruik om atoombomme te vervaardig, wanneer die tegniek van voorbehoedmiddele ontwikkel word en dit word ook buite die huwelik gebruik, wanneer die druk van boeke en die maak van films gebruik word om pornografie te produseer, wanneer fabrieke en laboratoria to milieubesoedêling bydra - kortom, wanneer wetenskaplik verworwe kennis misbruik word, mag die wetenskaplike dan swyg? Of moet hulle op die een of ander wyse optree? Is dit nie die taak van die wetenskaplikes om as gewete van die samelewing op te tree of selfs medewerking te weier waar wetenskaplike resultate misbruik word nie? As daar destyds in Europa met die begin van die kolonisasiebeleid ernstig aandag gegee was aan die etiese dimensie van die beleid, sou baie van die negatiewe gevolge daarvan waarskynlik voorkom kon gewees het die ryk word van baie lande ten koste van die kolonies, en die afkeer by volke uit Afrika en Asië teen die Blankes - 'n afkeer wat tans deur die kommuniste uitgebuit word.

4.7.4 Juis omdat die etiese intrinsiek eie is aan die wetenskap, mag die beoefenaars van die wetenskap hulle nie daaraan onttrek nie en die deur die wetenskaplike arbeid ontstane etiese probleme onbeantwoord laat, of, erger nog, aan ander sg. gekwalifiseerde etici - bv. in teologie of in 
filosofie - oorlaat nie. Afgesien daarvan dat die wetenskaplike as wetenskaplike met etiese probleme gekonfronteer is, is hy gewoon ook as mens ' $n$ etiese wese wat vir sy dade en die konsekwensies daarvan, verantwoordelik is. Die navorser mag sy verpligting tot etiese beslissinge nie ontvlug of delegeer - dit selfs nie aan 'n instelling soos bv. die kerk oorlaat nie. $\mathrm{Hy}$ is as mens aan God verantwoording verskuldig vir wat hy doen - hoe hy dit doen, waarom hy dit doen en vir die gevolge van wat hy doen.

4.7.5 Kategories mag beweer word dat die etiese aspek van die wetenskap veels te weinig, indien selfs enige, aandag ontvang - van die beoefenaars daarvan, maar ook van die inrigtings wat met reg as die tuiste van die wetenskap beskou kan word, $\mathrm{nl}$. die skool en die universiteit. Dit moet as 'n onreg teenoor die student beskou word as hy nie bewustelik en sistematies met die etiese dimensie van sy besondere wetenskap of wetenskappe vertroud gemaak word nie, en só van sy eie persoonlike sosiale verantwoordelikheid. 'n Eensydige aksentuering van die kennisaspek van die wetenskap met verwaarlosing van die etiese dimensie en die verontskuldiging dat die etiese - of dan wel iets van die etiese - deur instellinge soos die gesin, Christelike organisasies en die pastorale bemoeienis van die kerk, behartig word, is net nie verantwoord nie. Die opleiding van die student is nie afgerond en kompleet as hy eers later in sy lewe met etiese probleme gekonfronteer word nie - waarvoor hy nie eers behoorlik voorberei is nie. Dat etiek slegs in die teologie en in die filosofie sistematies bestudeer word, en hoogstens in die geneeskunde ook aandag kry, is sekerlik nie voldoende nie. Aan die etiese in elke wetenskap sal aandag gegee moet word. Só kom die student in aanraking met die objektiewe etiese struktuur van die wetenskap en leer hy meteen ook sy persoonlike betrokkenheid by en onderworpenheid aan die etiese appêl.

4.7.6 Om twee redes is ' $n$ omvattende sosiaal-etiese beleid vir die universiteit meer as ooit te vore dringend noodsaaklik. Ten eerste as gevolg van die groter wordende relevansie wat die etiese dimensie van die wetenskap in ons moderne tyd besig is om te verkry, en ten tweede, omdat die universiteit self nie (meer) as 'n geïsoleerde instelling los van die samelewing, beskou kan word nie. 'n Optimaal-humane samelewing kan in die huidige wèreld met sy moderne tegniese en wetenskaplike kultuuraktiwiteite net nie aan die natuurlike verloop van sake oorgelaat word nie. In die bewuste en wetenskaplik-begronde vormgewing van so 'n samelewing, het die universiteit ' $n$ enorme groot funksie te vervul. Maar dan sal die universiteitsbeleid ten opsigte van 'n positivistiese wetenskaps- 
beskouing, waarin die wetenskap soveel moontlik beperk word tot ' $n$ deskriptiewe funksie met uitsluiting van die eties-normatiewe, moet verander, en die universiteitsbeleid t.o.v. die wetenskapsonderrig, sal die etiese moet insluit. As ons dus pleit vir 'n geïntegreerde akademiese opleiding, pleit ons dat alle aspekte van die wetenskap - ook die etiese - volledige aandag sal ontvang en intensief uitgebou sal word, maar ons pleit óók dat die universiteit sy betrokkenheid by die gemeenskap, nie net teoreties sal bely nie, maar ook prakties sal konkretiseer. Wat ons dringend nodig het is ' $n$ fundamentele taakverbreding en taakverdieping van die universiteit - só kan ook die universiteit die akademiese gewete word vir die samelewing. Eweneens sal die skool sy taak t.o.v. verantwoorde etiese opvoeding deeglik moet verstaan, en die kinders van vroeg af hulle verantwoordelikheid teenoor die samelewing in die algemeen en teenoor hulle medemense in besonder laat besef. Daarvoor sou 'n inleidende vak soos "samelewingsleer" uitstekende diens kon verrig en sal deur onderwysers eweneens aandag aan die etiese dimensie van die wetenskap gegee moet word.

\section{Bibliografie}

Antonites, A.J., Die wetenskapsbegrip by die Neo-Calvinistiese Wysbegeerte, Pretoria 1972.

Barth, K., K.D. 11/1, Zürich 1946.

Brunner, E., Philosophie und Offenbarung, Tübingen 1925.

Dippel, C.J., Geloof en Natuurwetenschap, deel 2, 's-Gravenhage 1967.

Esterhuyse, W.P., Wetenskap en Maatskappy, Johannesburg 1975.

Heering, G.J., Geloof en Openbaring, Arnhem 1950.

Heyns, J.A. en Jonker, W.D., Op weg met die teologie, Pretoria 1974.

Heyns, J.A., Teologiese Etiek, deel 1, Pretoria 1982.

Kwant, R., "Ethische vragen rond wetenschapsbeoefening en techniek", in: Research Ethiek, Haarlem 1962.

Luijpen, W., Existentiële Fenomenologie, Utrecht 1959.

Oberholzer, C.K., Die Vryheidsgedagte in die moderne opvoeding, Pretoria 1942.

Oberholzer, C.K., Prolegomena van 'n prinsipiële pedagogiek, Pretoria 1968.

Roscam Abbing, P.J., Rondom het Woord, Jrg. 11, no. 2 Hilversum 1969.

Schuurman, E., The scientification of modern culture, I.B.C. no. 124, Potchefstroom, 1978.

Stoker, H.G., Beginsels en metodes in die wetenskap, Potchefstroom 1961.

Van Melsen, A.G.M., Natuunwetenschap en Ethiek, Antwerpen 1967.

Van Peursen, C.A., Fenomenologie en werkelijkheid, Utrecht 1967.

Van Peursen, C.A., Wetenschappen en werkelijkheid, Kampen 1969.

Von Weizacker, C.F., The relevance of Science, London 1959. 